\title{
START-UP VENTURES: EMERGING TRENDS AND IT'S IMPACT ON GROWTH \& DEVELOPMENT OF INDIAN ECONOMY
}

\author{
Dr. Rakesh Kumar \\ Assistant Professor \\ Faculty of Commerce \\ Shaheed Mangal Pandey Govt. Girls (P.G.) \\ College, Meerut-250001 Uttar Pradesh
}

\author{
Shilpi Tyagi \\ Research Scholar, Faculty of Commerce \\ Shaheed Mangal Pandey Government Girls \\ (P.G.) College, Meerut \\ Uttar Pradesh, India
}

\begin{abstract}
Changes in the environment lead to generation of ideas to combat the difficulties related to particular time period. Concept of startup is not an exception of it. Various factors giving push for growth of startups in India includes Individuals urge on gaining professional qualification, mobile penetration and increasing internet connectivity, Government initiatives are some of the reasons that affect the decision of starting a venture. Government's initiative of Make in India and Atmanirbhar Bharat has instilled some sense of confidence in young entrepreneurs to come up with business ideas and side by side Covid 19 pandemic has led to increase in number of ventures related Internet. Today's environment seems to be more helpful to entrepreneurs in terms of government support. It is about the constant motivation individuals are getting from leader of the nation. No doubt journey to start a venture is not an easy task but continuous assurance from a leader makes people more confident. Startups in India are not only proving itself beneficial for nation's economy but also for the individuals who are underemployed or are not satisfied with their current working situation and satisfaction is the key component in delivering the best in each and every sphere of life.
\end{abstract}

\section{Aim of Paper}

This paper aims to give the understanding of various factors affecting startups and its emerging trends in India along with understanding of the environment in which business exist. Paper will also highlight the factors affecting growth of startups in Indian economy and to analyze the importance of entrepreneurship in the development of Nation.

\section{Key Words-}

Startups, Atmanirbhar Bharat, Leaderships, Entrepreneurs, Growth, Innovation, Business Environment, and Internet. 


\section{INTRODUCTION}

A company operating in its nascent stage and is founded by one or more entrepreneurs is termed as start up. The ultimate goal of startup is to convert the ideas into business model which is not possible while working for someone else with complete freedom. More and more people are coming up with concepts which were untouched in past. Any business is surrounded by the dynamic environment. Government of India has introduced eligibility criteria for a firm to be recognized as start up. The criteria are as follows:

- The startup must be registered as a private limited company or as partnership firm or LLP.

- Total turnover of the organization should be less than rupees 100 crores in the previous financial year.

- An entity will be considered start up for initial 10 years from the date of its registration.

- The startup must be working toward innovation / improvement of existing products, services and processes and should have the potential to generate employment/create wealth.

- An entity formed by reconstruction/ splitting up of existing operating business shall not be considered as start up in India.

Indian start-ups ecosystem has seen remarkable growth over a period of time. Any business exists in environment which comprise of internal and external environment (further divided into micro and macro environment). Various factors related to the environment affect the start and growth of business (concepts). Startups have played the significant role in the growth, development of Indian economy. Startups are likely to become the epitome of industrial growth in Indian economy. Startups can be key player in generating employments and reducing unemployment and underemployment to some extent.

India is moving forward to have 100 unicorns by 2025(report by TiE Delhi-NCR and Zinnov titled 'Covid 19 and the anti-fragility of Indian start up ecosystem', retrieved online from Business line, The Hindu).

A decade ago start-ups were limited to few players but technological advancement, increase in literacy and education, exposure to internet which has bring world to the same platform , career oriented courses, people with zeal to raise their standard of living lead to increase in start-ups .Some of the examples of start-ups are BYJUs, PayTm, Zomato, Swiggy, Big Basket.

Recent changes in the environment pose challenges to the growth of business. But the idea to combat these challenges opens new ways to tackle difficulties of a time period. Therefore situations lead to developing new ideas for start-ups. Like year 2020 world faced the biggest challenge of all time Covid 19. Due to which economies suffered a lot as businesses had to be closed (temporarily) in order to save lives. This results in loss of income and jobs. People come up with ideas to operate their businesses online which are based on "no contact" delivery. This has lead to creation of competition in internet driven market. Number of key players emerged in health market, education sector, food sector, entertainment field. But approximately $40 \%$ of start-ups were negatively impacted during lockdown period. However pace of development was regained as the economy opened.

Government played pivotal role in the development of start-ups by encouraging people to go for local products. One of the examples was to banning tiktok, pubg which leads 
to Indian players to take the vacant position. Generating the sense of Atmanirbhar Bharat among citizens. Government scheme targets not only the urban people but rural entrepreneurs also. They are giving equal opportunities to male and female entrepreneurs.

Startup India programme was launched by Honourable Prime Minister Shri Narendra Modi on 16 January 2016 with an intention to create a strong ecosystem for the growth of start-ups and creating a entrepreneur friendly environment. To improve the overall condition of new ventures a system should be established which must have all the information regarding financial support, technical support. Policies must be cleared to the entrepreneurs so that hassle free environment can be created. Transparency brings in the sense of trust and confidence which a government must succeed to incorporate in venture enthusiasts so that more and more individuals with knowledge can be attracted to contribute in growth. A job like security but a owner like freedom must be given to entrepreneurs. The ecosystem in which startups exist should be friendly towards the new entrepreneurs and not aggressive and the exit policies are also required to give due consideration.

\section{Literature Review}

Diana Hechavarria \& Paul Reynolds(2009), "Cultural norms \& business start-ups: The impact of national values on opportunity and necessity entrepreneurs". Paper discusses the important role played by culture in shaping entrepreneurial behavior. Paper also gives in depth insight into the various dimensions of culture and their impact on entrepreneurship.

Radha Iyer et al(2014), "Factors That Influence Entrepreneurship in India - an Exploratory Study". The paper studies the various factors that affect entrepreneurship and their success. The paper gives an insight into the various parameters which can affect entrepreneurship. Paper give the clear understanding that entrepreneurship is affected by internal factors (motivation, risk bearing capacity) and external factors (economic, demographic, cultural, social, environment).

Paper layout the importance various factors related to entrepreneurship. Gives due consideration to the role of family (educational background of parent) in developing entrepreneurial attitude and observed the importance of regulatory framework (government policies) in the development process of start-ups.

A.K. Dwivedi (2016), "Educating Youth to Launch and Sustain Business Start-Ups". The paper is basically to provide an understanding of entrepreneurship. Paper creates awareness about the startups and also studies the motivational factor to make youth enthusiastic about starting the business. Author lays emphasis on the development of curriculum in the academic institutions.

Paper states the importance of creating awareness among students. Author also discusses about the faculty development program related to entrepreneurship so that proper mentoring can be provided to budding entrepreneurs.

Dr Suniti Chandiok (2016), "India the world's fastest growing start up ecosystem: A Study. As stated by author there are three stages of start-up in start-up ecosystem as pre start up (discovery and validation), start up (efficiency, scale), Growth (maintenance, sale/renewal). Paper states that funding is the major driving force for the growth of startups. Paper is handful in understanding the various financial concepts of start-ups funding.

Ankita Barik ,Bhavesh Vanparia \& Lal Barik(2017), "Impact of Social-Cultural Factors on Entrepreneurs in India”. Paper states about the importance of impact of cultural values in 
the decision making process related to start ups. Paper also discusses about the various influences on entrepreneurs as peers, unemployment, social networking which contributes in making a decision regarding starting the venture and sustaining growth. Education also has the remarkable effect in shaping entrepreneur's behaviour.

James Okrah, Alexander Nepp,Ebenezer Agbozo(2018), "Exploring the factors of startup success and growth Article". Paper studies various factors which results in success of startups like research and development and financing as dependent variables $\&$ government policies, internal market openness, internal market dynamic as independent variables with GDP per capita and employment as controlled variables. Paper states that government plays major role in success and growth of start-ups.

Dr. G Suresh Babu and Dr. K Sridevi(2019), A Study of Issues and Challenges of startups in India". This paper thoroughly studies the Startups India plans introduced by Government of India. Paper aims to study challenges like availability of financial support, revenue generation, and lack of mentorship, regulation and infrastructural facilities. Paper gives a clear understanding of various initiatives taken by government to promote entrepreneurs.

Kamala Kannan Dinesh \& Professor Sushil(2019), "Strategic innovation factors in startups: results of a cross-case analysis of Indian startups". The paper studies two case studies related to two different startups with different operations to develop theory. Paper lays emphasis on the innovativeness in every aspect like marketing, resource management, sales channels, operations, team learning, and strategic networking. The two startups (Product based start-ups and Service based start-ups) were studied on various parameters of innovativeness.

Sabrina Korreck(2019), “The Indian start up Ecosystem: Drivers, Challenges and Pillars of Support". The author tries to generate an understanding of challenges and growth catalyst of start-ups. Paper states about some of the factors like technological progress, increased government (political) will, shift in the attitude of existing firms who are outsourcing and taking helps of start-ups in terms of innovativeness and personal motivation of an individual to take decisions creatively which acts as driving force for start-ups.

Paper also studies the geographical environment in which entrepreneurial activities are taking place. Which cities are coming up with more and more start-ups and what are forces leading to growth in particular region? It studies about the availability of resources and infrastructural facilities in these cities.

Gurpreet Vilkhoo(2020), “A Report on Consumer Internet Startup Ecosystem in India 2020"Author studies the scenario of start-ups during the Covid 19 pandemic and online startups, their challenges and support provided by government, startup valuation. Paper studies he various start-ups at various parameters.

\section{Factors affecting the growth of start-ups in India}

Internal/intrinsic Factors

- Values decide the kind of business one wants to operate, objectives one wants to attain through the particular choice and ethics decides the direction of the business.

- Internal Power Relationship affects the growth of start-ups as there will be difference in operating system if an enterprise is founded by one individual or team (founders and cofounders). 
- Availability of human resource is critical for the success of startups. As any start up would need an employee with expertise and knowledge in the particular field. Good amount of remuneration should be provided accordingly. Otherwise employee may feel less motivated.

- Research and development (innovation) is the key of entrepreneurship. Startups are required to be equipped with facilities which are needed to carry out research.

- Financing poses major challenge to start-ups. Capital generation is as important as idea generation.

External/ Extrinsic Factors

- Economic Factors related to any nation affects the industrial growth. Several economic policies like trade policies, industrial policy, foreign exchange policy taxation, patents are some of the economic factors that affect start-ups success.

- Political will and Government support are also the factors that affect growth of startups. Government plays various roles like planning, promotional, regulatory. One role of Motivator has taken front seat in present political scenario as people have become habitual of listening to their leader and taking cue from them.

- Technological factors play pivotal role in the success of start-ups as start-ups are based on the idea to invent, to find the creative solution for the problem. Startups need to be equipped with proper knowledge and appropriate technology.

- Demographic factors seem to be contributor in the growth of startups. Education, age structure, family cycle, gender, family income and distribution are some of the related factors

- Societal factors/ Cultural factors equally affect acceptance and growth of startups. Value system of founders is determined by the cultural factors. Beliefs, tastes and preferences are shaped by culture. There are various cultural traits which affect decision making capability of an individual and shaping the initiation and growth of start-ups.

- Expectations of the customers affect the growth of start-ups. A wide range of products and services are available to customers at reasonable price. This creates standard of expectations in customers' mind. Customers are equipped with various information sources that make them intelligent decision makers.

- Natural Factors affect the growth of start-ups. As year 2020 will be remembered for spread of Covid 19. Most of the nations were affected by the pandemic. This pandemic and resulted lock down affected economies adversely. But a significant growth is seen in online start-ups. Threats turned into opportunities by some of the entrepreneurs.

\section{Limitation of the Study}

Major limitation of the study is that it is based on secondary data. A limited analysis of study was possible in the due time. More time needed to study related studies/researches so that a comparative and more comprehensive conclusion can be reached. More primary studies are required to be done and clear message and suggestions should be given to government, people concerned. Proper channel should be made so that the studies done so far can be applied in practical life. Most of the factors are tried to cover but the dimensions and factors are vast and they all are not able to be covered in the present study. 


\section{Conclusion}

Present economic scenario is favorable to the development of start-ups. The Indian government is equally willing and enthusiastic in promoting start-ups. People are also becoming confident in terms of taking risk. The startup field is surrounded by various challenges ranging from financing, availability of resources (work force, technology, raw material) to infrastructural facilities. Startups plans are largely affected by educational background of an individual and peers related to that person. People need to sharp and creative. Entrepreneurs should have the ability to not only think out of the box but to create limitless boxes without defined boundaries for others. Following are some suggestions for better implementation of policy of government if India as regards Startups-

- Entrepreneurship should be incorporated in course work and Proper training should be conducted to impart awareness and solve queries.

- Proper mentorship is the need of the hour. Large enterprises should have the social responsibility to collaborate with universities and colleges to mentor and provide required financial assistance to the talented individuals.

- Success and failure story of start-ups should be included in course work to create an understanding of various dimensions related to start-ups.

- Government policies should be made transparent. Mottos can provide encouragement but ease of doing business and clear policies create a sense of belief and trust in start-ups.

- Government should provide "idealist" to aspirants. This list could be helpful in germinating the seeds of concept creation in budding entrepreneurs.

- Marketing activities should be made in alliance with various factors affecting the growth of start-ups. Marketing should be paid proper attention like fully fledged businesses do.

- Various Programmes are being operated by government but people are unaware. Government should conduct various activities to create awareness among people who are interested and can avail the opportunities. These programs can be run in partnership with banks (can be the source of loan: capital generation).

- Exit programs should also be taught as entrepreneurs should be well aware about them so that they can exit business anytime they feel less confident or business seems to not so profitable.

\section{Reference-}

$>$ Ankita Barik ,Bhavesh Vanparia \& Lal Barik, "Impact of Social-Cultural Factors on Entrepreneurs in India”, International Journal of Current Engineering and Scientific Research, 4, 2017,DOI 10.21276/ijcesr/2017.4.7.1.

> A.K. Dwivedi, "Educating Youth to Launch and Sustain Business Start-Ups", University News, 2016, 54(39), DOI 10.2139/ssrn.2858755.

> Diana Hechavarria \& Paul Reynolds, "Cultural norms \& business start-ups: The impact of national values on opportunity and necessity entrepreneurs", International Entrepreneurship and Management Journal (5)l,December 2009, DOI 10.1007/s1 1365-009-0115-6.

> Dr. G Suresh Babu and Dr. K Sridevi, A Study of Issues and Challenges of startups in India”, International Journal of Financial Management and Economics, 2(1),2019.

Dr Suniti Chandiok, "India the world's fastest growing start up ecosystem: A Study",Amity Research Journal of Tourism, Aviation and Hospitality, 01(2), July-Dec 2016. 
Francis Cherunilam, "Business Environment" Text and cases, Himalaya Publishing House, $18^{\text {th }}$ Revised Edition: 2008,Pg 3-32.

$>$ Gurpreet Vilkhoo, “A Report on Consumer Internet Startup Ecosystem in India 2020”,June 2020,online retrieved, DOI 10.13140/RG.2.2.26922.64960.

> James Okrah, Alexander Nepp,Ebenezer Agbozo, "Exploring the factors of startup success and growth Article”, The Business and Management Review, 9(3), April 2018.

$>$ Kamala Kannan Dinesh \& Professor Sushil , "Strategic innovation factors in startups: results of a cross-case analysis of Indian startups", J for Global Business Advancement, 12(3) , July 2019, DOI 10.1504/JGBA.2019.101387.

$>$ Radha Iyer et al, "Factors That Influence Entrepreneurship in India - an Exploratory Study”, September 2014( online retrieved from www.researchgate.net).

> Sabrina Korreck, "The Indian start up Ecosystem: Drivers, Challenges and Pillars of Support”, ORF Occasional Paper No. 210, September 2019, Observer Research Foundation

The Hindu, Business Line, Covid Impact: 40\% of startups hit but recovery is strong, 14 October 2020

$>$ www.startupindia.gov.in 